\title{
Przemysław Nosal
}

Uniwersytet im. Adama Mickiewicza w Poznaniu

Natalia Wasielewska

Regionalny Ośrodek Polityki Społecznej w Poznaniu

http://dx.doi.org/10.18778/8088-074-0.06

\section{Niepełnosprawny jako pracujący w systemie ekonomii społecznej}

\section{STRESZCZENIE}

Ekonomia społeczna to obszar, w którym za sprawą określonych działań o charakterze gospodarczym dokonuje się proces integracji grup wykluczonych lub zagrożonych wykluczeniem społecznym. Jedną z takich grup są osoby niepełnosprawne. Tekst ten pokazuje, w jaki sposób integracja ta odbywa się w ramach trzech typów podmiotów: warsztatach terapii zajęciowej, zakładach aktywności zawodowej oraz spółdzielniach socjalnych osób niepełnosprawnych. W artykule wskazane są zarówno zasługi i mocne strony tych podmiotów, ale także problemy związane z ich funkcjonowaniem.

Słowa kluczowe: rynek pracy, ekonomia społeczna, przedsiębiorczość społeczna, spółdzielnia socjalna, warsztat terapii zajęciowej, zakład aktywności zawodowej.

\section{OSOBY NIEPEŁNOSPRAWNE I PRACA}

Aktywna obecność osób niepełnosprawnych w przestrzeni publicznej wymaga ich społecznego „zakorzenienia” w obszarach, które wykraczają poza sferę prywatną, czyli dom i rodzinę. Pól możliwej partycypacji jest oczywiście wiele kultura, sztuka, sport, wspólnoty lokalne, nauka czy polityka. To jednak rynek pracy pozostaje przestrzenią wyjątkową. 
Dzięki obecności na rynku pracy osoby te nie tylko stają się pracownikami, ale także uczestniczą w całym szeregu procesów o znacznie szerszym kontekście społecznym. W niniejszym tomie znajduje się już artykuł Niepełnosprawny jako pracownik i pracodawca opisujący wielowymiarowość procesu wcielania się osoby niepełnosprawnej w rolę pracownika. W tym miejscu należałoby więc tylko wskazać cztery aspekty integracji społecznej związane z nabywaniem obowiązków zawodowych.

Po pierwsze, praca stanowi jeden z najważniejszych przyczynków do redefiniowania „ja” osób niepełnosprawnych. Dzięki efektywnemu funkcjonowaniu na tak trudnym polu, jakim jest rynek zatrudnienia, osoby te zmieniają postrzeganie siebie - mają większą wiarę we własne umiejętności, lepiej oceniają swoje szanse na sukces, czują się bardziej samodzielne (zob. np. Brzezińska, Kaczan, Rycielska 2010: 61-64).

Po drugie, praca dowartościowuje społecznie osoby niepełnosprawne jako jednostki „użyteczne społecznie” lub - używając kluczowej obecnie kategorii neoliberalnego dyskursu - „produktywne”. Ich aktywność zawodowa sprawia, że czują się one równoprawnymi członkami społeczeństwa (choć oczywiście są nimi także wtedy, gdy nie pracują). Dzielą bowiem z innymi ludźmi - również tymi dalszymi albo zupełnie odległymi, np. oglądanymi w telewizji - podobne problemy i wyzwania. Są to np. rutyna codzienności, organizacja dnia, mobilność/przemieszczanie się, zarobki czy też wydatki z tym związane.

Po trzecie, praca stanowi dla osób niepełnosprawnych nie tylko aktywność o charakterze (wy)twórczym lub produkcyjnym, ale jest również procesem nabywania kompetencji ogólnożyciowych: samodyscypliny, wykonywania poleceń i kreatywnego myślenia, umiejętności nawiązywania kontaktów, życia w grupie, samoorganizacji. To wszystko sprawia, że rola pracownika, w kontekście integracyjnym jest - stosując znowu popularny w socjologii przedrostek - 
„megarolą”. Praca pozostaje więc socjalizacyjnym „kombajnem", uczy osoby niepełnosprawne nie tylko pracy, ale i życia w społeczeństwie. Dzięki niej budują (lub rozbudowują) swój kapitał ekonomiczny, ale także inne kapitały - społeczny i kulturowy.

Po czwarte, akt czasowej zmiany środowiska - z rodzinnego na zawodowe - stanowi każdorazowo niezwykle ważny moment $\mathrm{w}$ procesie integracji społecznej osoby niepełnosprawnej. Staje się on bowiem synonimem treningu ról społecznych - goffmanowskich dekoracji, zespołów, scen, kulis i kostiumów (zob. Goffman 1981). Dzięki temu doświadcza ona mnogości ról, w które wchodzi się każdego dnia, a także złożoności świata społecznego.

Po piąte wreszcie, praca zawodowa jest podstawową formą zarabiania pieniędzy. Osobiste dysponowanie nimi stanowi zaś dla osób niepełnosprawnych jeden $\mathrm{z}$ najważniejszych przejawów samodzielności i niezależności. Tym samym umożliwia (albo ułatwia) ono wpisanie się osób niepełnosprawnych w jeden $\mathrm{z}$ głównych nurtów uczestnictwa w życiu społecznym - konsumpcję.

Praca zawodowa pozostaje zatem niezwykle istotnym aspektem aktywności życiowej osób niepełnosprawnych.

\section{Osoby niepełnosprawne na rynku pracy - stan obecny i dynamika zjawiska}

Według danych Narodowego Spisu Powszechnego z 2011 r. w Polsce żyje około 4,7 mln (dokładnie 4 697,5 tys.) osób niepełnosprawnych ${ }^{1}$. Stanowią one zatem 12,2\% ludności całego państwa. Biorąc pod uwagę, że tworzą one tak dużą populację, to kwestią szczególnej troski ze strony decydentów polityki społecznej powinno być zagadnienie ich ulokowania na rynku pracy.

1 Za: http://stat.gov.pl/spisy-powszechne/nsp-2011/nsp-2011-wyniki/ (dostęp 16.10.2015). 
Według Badania Aktywności Ekonomicznej Ludności $(\mathrm{BAEL})^{2}$ prowadzonego przez Główny Urząd Statystyczny (GUS) udział osób niepełnosprawnych ze znacznym stopniem niepełnosprawności w całej populacji osób niepełnosprawnych w 2014 r. wynosił $28,4 \%$, z umiarkowanym - 42,3\%, z lekkim - 29,3\%. Wśród osób niepełnosprawnych $\mathrm{w}$ wieku produkcyjnym (bo to właśnie ta kategoria jest kluczowa dla rynku pracy) owa struktura przedstawiała się następująco: 22,0\% - znaczny stopień niepełnosprawności, 45,0\% - umiarkowany, 33,0\% - lekki.

W kontekście statystyk związanych już z samym rynkiem zatrudnienia należy odnotować, że w I kwartale $2015 \mathrm{r}$. współczynnik aktywności zawodowej (tj. udział ludności aktywnej zawodowo [osoby w wieku 15 lat i więcej należące do pracujących lub bezrobotnych] w ogólnej liczbie ludności w wieku 15 lat i więcej lub danej grupy) ${ }^{3}$ wyniósł 16,6\%; wskaźnik zatrudnienia (tj. udział pracujących w ogólnej liczbie ludności w wieku 15 lat i więcej $)^{4}-14,1 \%$, a stopa bezrobocia (tj. stosunek liczby osób bezrobotnych do liczby ludności aktywnej ekonomicznie, czyli zasobu siły roboczej danej populacji $)^{5}-16,1 \%$.

W tym miejscu należy podkreślić, że ważnym czynnikiem wspierającym zatrudnienie osób niepełnosprawnych jest fakt, że podmioty dające im pracę mogą liczyć na szereg udogodnień. Po pierwsze, mają one charakter zwrotu określonych kosztów: adaptacji pomieszczeń do potrzeb osób niepełnosprawnych; adaptacji lub nabycia urządzeń ułatwiających osobie niepełnosprawnej wykonywanie pracy lub

2 Za: http://stat.gov.pl/informacja-o-badaniach-ankietowych/badanie-aktywnosci-ekonomicznej-ludnosci-bael/ (dostęp 16.10.2015).

$3 \mathrm{Za}:$ http://stat.gov.pl/metainformacje/slownik-pojec/pojecia-stosowane-w-statystyce-publicznej/591, pojecie.html (dostęp 16.10.2015).

$4 \mathrm{Za}$ : http://stat.gov.pl/metainformacje/slownik-pojec/pojecia-stosowane-w-statystyce-publicznej/884, pojecie.html (dostęp 16.10.2015).

$5 \mathrm{Za}:$ http://stat.gov.pl/metainformacje/slownik-pojec/pojecia-stosowane-w-statystyce-publicznej/486, pojecie.html (dostęp 16.10.2015). 
funkcjonowanie w zakładzie pracy oraz zakupu i autoryzacji oprogramowania na użytek pracowników niepełnosprawnych i urządzeń technologii wspomagających lub przystosowanych do potrzeb wynikających $\mathrm{z}$ ich niepełnosprawności. Po drugie, wiążą się one $z$ miesięcznym dofinansowaniem do wynagrodzenia pracownika niepełnosprawnego. Po trzecie, dotyczą refundacji kosztów zatrudnienia pracownika pomagającego osobie niepełnosprawnej. Po czwarte, obejmują zwrot kosztów wyposażenia stanowiska pracy stworzonego dla osoby niepełnosprawnej oraz zwrot kosztów szkolenia pracowników niepełnosprawnych. Po piąte, zapewniają refundację $\mathrm{z}$ tytułu zatrudnienia $\mathrm{w}$ ramach prac interwencyjnych osoby niepełnosprawnej zarejestrowanej w powiatowym urzędzie pracy, $\mathrm{z}$ tytułu zatrudnienia $\mathrm{w}$ ramach robót publicznych osoby niepełnosprawnej zarejestrowanej $\mathrm{w}$ powiatowym urzędzie pracy oraz $\mathrm{z}$ tytułu przyjęcia na przygotowanie zawodowe dorosłej osoby niepełnosprawnej zarejestrowanej w powiatowym urzędzie pracy.

Istnieje więc szereg rzeczywistych korzyści wynikających z zatrudniania osób niepełnosprawnych.

\section{Główne problemy dotyczące obecności osób} niepełnosprawnych na rynku pracy

Satysfakcjonująca dla wszystkich zainteresowanych stron obecność osób niepełnosprawnych na rynku pracy natrafia jednak na liczne przeszkody, które sprawiają, że odsetek pracujących osób niepełnosprawnych jest wciąż stosunkowo niewielki. Można wskazać pięć głównych grup takich barier:

- bariery mentalne pracodawców - lęk pracodawców przed zatrudnianiem osób niepełnosprawnych - obawa związana $\mathrm{z}$ tym, że osoby niepełnosprawne będą gorszymi pracownikami niż osoby pełnosprawne - mniej efektywnymi, gorzej adaptującymi się w nowym środowisku, mniej zaangażowanymi w pracę, bardziej roszczeniowymi, częściej chorującymi itd.; 
jednocześnie w kategorii barier mentalnych pracodawców należy rozpatrywać nieznajomość korzyści płynących z zatrudniania osób niepełnosprawnych (wskazanych kilka akapitów wyżej);

- bariery mentalne osób niepełnosprawnych (pracowników) - lęk przed samym wejściem na rynek pracy (a co za tym idzie - opuszczeniem bezpiecznego otoczenia rodzinno-koleżeńskiego) bardzo często sprawia, że osoby niepełnosprawne nie decydują się na taki krok; drugą barierą w tym obszarze jest natomiast lęk przed utratą świadczeń rentowych po podjęciu pracy.

- bariery fizyczne (jednostkowe) osób niepełnosprawnych - przypadek każdej osoby niepełnosprawnej jest inny, ale wiele typów niepełnosprawności w rzeczywistości uniemożliwia podjęcie określonych aktywności zawodowych (np. pracy o charakterze fizycznym);

- bariery kwalifikacyjne osób niepełnosprawnych - wielu pracodawcom towarzyszy przekonanie, że osoby niepełnosprawne dysponują gorszymi kwalifikacjami zawodowymi niż osoby pełnosprawne, w związku z tym wolą zatrudniać pracowników z tej drugiej grupy; jednocześnie należy także zauważyć, że w kontekście wielu zawodów bariery kwalifikacyjne rzeczywiście istnieją i związane są one przede wszystkim z określoną ścieżką edukacyjną, którą realizowały osoby niepełnosprawne (np. niemożność ukończenia szkoły zawodowej);

- bariery infrastrukturalne - wiele zakładów pracy wciąż jest nieprzystosowanych do obecności osób niepełnosprawnych; pracodawcy zamiast dokonać stosownych reorganizacji utrzymują jednak ten stan przestrzennego wykluczania;

- bariery systemowo-strukturalne - rynek pracy dla osób niepełnosprawnych wciąż oferuje zbyt mało miejsc w stosunku do popytu na nie; 
Mając na uwadze wszystkie powyższe bariery, należy jednak zauważyć, że każdą z nich można umniejszyć poprzez podjęcie odpowiednio sprofilowanych działań.

\section{Instytucje wspierające osoby niepełnosprawne} na rynku pracy

Działania nakierowane na wsparcie obecności osób niepełnosprawnych na rynku pracy podejmuje szereg podmiotów i instytucji. Oto najważniejsze z nich:

- Państwowy Fundusz Rehabilitacji Osób Niepełnosprawnych (PFRON) - to fundusz, którego środki przeznaczane są na działania związane $\mathrm{z}$ rehabilitacją zawodową i społeczną osób niepełnosprawnych, a także na ich zatrudnianie. Pieniądze kierowane są m.in. na: rekompensatę pracodawcom chronionego i otwartego rynku pracy podwyższonych kosztów związanych z zatrudnianiem osób niepełnosprawnych (dofinansowanie do wynagrodzeń); refundację pracodawcom kosztów przystosowania, adaptacji i wyposażenia miejsc pracy osób niepełnosprawnych; dofinansowanie tworzenia i funkcjonowania warsztatów terapii zajęciowej oraz zakładów aktywności zawodowej; zlecanie organizacjom pozarządowym i fundacjom realizacji zadań z zakresu rehabilitacji zawodowej i społecznej osób niepełnosprawnych; współfinansowanie projektów systemowych realizowanych ze środków pomocowych Unii Europejskiej; wspieranie indywidualnych osób niepełnosprawnych poprzez: udzielanie dotacji na rozpoczęcie działalności gospodarczej, rolniczej lub wniesienie wkładu do spółdzielni socjalnej, refundację składek na ubezpieczenia społeczne dla osób prowadzących działalność gospodarczą, niepełnosprawnych rolników oraz rolników zobowiązanych do opłacania składek za niepełnosprawnego domownika, dofinansowanie: likwidacji barier architektonicznych, w komunikowaniu 
się i technicznych, zakupu sprzętu rehabilitacyjnego, przedmiotów ortopedycznych i środków pomocniczych oraz turnusów rehabilitacyjnych, programów PFRON (dysponentem środków w tym wypadku jest przede wszystkim Powiatowe Centrum Pomocy Rodzinie); oraz finansowanie aktywnych instrumentów rynku pracy dla osób zarejestrowanych jako bezrobotne lub poszukujące pracy (szkolenia, staże itp. $)^{6}$. Warto podkreślić, że Fundusz pozostaje jednym z najważniejszych dysponentów środków wspierających funkcjonowanie osób niepełnosprawnych na rynku pracy.

- Pełnomocnik Rządu ds. Osób Niepełnosprawnych - sekretarz stanu w urzędzie obsługującym ministra właściwego do spraw zabezpieczenia społecznego, powoływany i odwoływany przez Prezesa Rady Ministrów na wniosek Ministra Pracy i Polityki Społecznej. Do jego zadań należy m.in.: inicjowanie, nadzór i koordynacja nad wykonywaniem zadań wynikających z ustawy; inicjowanie kontroli realizacji zadań określonych w ustawie; żądanie od podmiotów informacji, dokumentów i sprawozdań okresowych dotyczących realizacji zadań; organizowanie konferencji i szkoleń; udzielanie informacji w sprawach z zakresu rehabilitacji zawodowej i społecznej oraz zatrudnienia osób niepełnosprawnych; opracowywanie standardów w zakresie realizacji zadań określonych w ustawie; opracowywanie oraz opiniowanie projektów aktów normatywnych dotyczących zatrudnienia, rehabilitacji oraz warunków życia osób niepełnosprawnych; opracowywanie projektów programów rządowych dotyczących rozwiązywania problemów osób niepełnosprawnych;

$6 \mathrm{Za}$ : http://www.pfron.org.pl/pl/pfron/1,PFRON.html (dostęp 16.10.2015). 
ustalanie założeń do rocznych planów rzeczowo-finansowych dotyczących realizacji zadań wynikających z ustawy; inicjowanie i realizacja działań zmierzających do ograniczenia skutków niepełnosprawności i barier utrudniających osobom niepełnosprawnym funkcjonowanie w społeczeństwie oraz współpraca $\mathrm{z}$ organizacjami pozarządowymi i fundacjami działającymi na rzecz osób niepełnosprawnych. Pełnomocnik wykonuje swoje zadania przy pomocy Biura Pełnomocnika Rządu do Spraw Osób Niepełnosprawnych (BON), które stanowi wyodrębnioną komórkę organizacyjną w Ministerstwie Pracy i Polityki Społecznej ${ }^{7}$.

- Sejmowa podkomisja stała ds. osób niepełnosprawnych - najważniejszy organ sejmowy dedykowany osobom niepełnosprawnym. Podkomisja działa w ramach Komisji Polityki Społecznej i Rodziny. Jej zadaniem pozostaje przede wszystkim praca o charakterze ustawodawczym w zakresie problemów osób niepełnosprawnych: ich funkcjonowania na rynku pracy, równego traktowania $\mathrm{w}$ zatrudnieniu, szans w oświacie, integracji społecznej oraz dostępu do rehabilitacji ${ }^{8}$.

- Związki pracodawców osób niepełnosprawnych - reprezentują interesy pracodawców osób niepełnosprawnych w licznych gremiach dialogowych na szczeblach lokalnych i centralnych, prowadzą działalność szkoleniowo-informacyjną oraz wspomagają zakładanie i funkcjonowanie ośrodków informacyjnych, centr aktywizacyjnych czy przedmiotowych stron internetowych. Do najważniejszych tego typu

7 Za: http://www.niepelnosprawni.gov.pl/p,12,pelnomocnik (dostęp 16.10.2015).

8 Za: http://www.sejm.gov.pl/SQL2.nsf/skladpkom7?OpenAgent\&PSR01S (dostęp 16.10.2015). 
związków należą: Polska Organizacja Pracodawców Osób Niepełnosprawnych (POPON), Krajowa Izba Gospodarczo-Rehabilitacyjna (KIG-R), Krajowy Związek Rewizyjny Spółdzielni Inwalidów i Spółdzielni Niewidomych (KZRSIiSN) czy Porozumienie Branżowe oraz Ogólnopolska Baza Pracodawców Osób Niepełnosprawnych (OBPON) ${ }^{9}$.

- Związki zawodowe pracowników osób niepełnosprawnych - są one coraz częściej zawiązywane przez niepełnosprawnych pracowników; należy także podkreślić, że ulegają systematycznemu usieciowieniu poprzez wchodzenie $\mathrm{w}$ rozliczne związki-federacje łączące większą liczbę organizacji, które w założeniu mają być partnerem dla organów samorządowych i państwowych (np. Federacja Związków Zawodowych Osób Niepełnosprawnych i Pracowników Zakładów Pracy Chronionej).

- Rzecznicy w instytucjach publicznych - coraz popularniejsze jest także tworzenie stanowiska rzecznika (lub pełnomocnika) osób niepełnosprawnych przy instytucjach publicznych - np. przy biurach prezydentów miast, starostów i wojewodów, w urzędach miast i gmin oraz na wyższych uczelniach. Zadaniem rzeczników/pełnomocników jest dbanie o interesy osób niepełnosprawnych (także o ich obecność na rynku pracy) w ramach funkcjonowania tych instytucji oraz ich bezpośredniego otoczenia.

9 Odrębnym przypadkiem są organizacje skupiające pracodawców osób niepełnosprawnych w ramach przedsiębiorstw społecznych. W tym obszarze działają takie organy, jak konwenty zakładów aktywności zawodowej, Ogólnopolski Związek Rewizyjny Spółdzielni Socjalnych (oba twory o ogólnopolskim charakterze) czy też fora warsztatów terapii zajęciowej (lokalnie). 


\section{Typy zatrudnienia}

Przyjmując pewną bardzo ramową klasyfikację, osoby niepełnosprawne mogą być zatrudniane w dwóch typach podmiotów: w funkcjonujących na otwartym rynku przedsiębiorstwach (firmach) albo w miejscach pracy dedykowanych osobom niepełnosprawnym. W tym drugim przypadku są to przede wszystkim zakłady pracy chronionej oraz zakłady aktywności zawodowej.

Status zakładu pracy chronionej od właściwego miejscu wojewody może otrzymać pracodawca, który prowadzi działalność gospodarczą przez okres co najmniej 12 miesięcy, zatrudnia nie mniej niż 25 pracowników w przeliczeniu na pełny wymiar czasu pracy, osiąga przez okres minimum 6 miesięcy wskaźnik zatrudnienia osób niepełnosprawnych w wysokości co najmniej 50\%, w tym co najmniej $20 \%$ ogółu zatrudnionych stanowić muszą osoby zaliczone do znacznego lub umiarkowanego stopnia niepełnosprawności (ten próg obowiązuje od 1 stycznia 2012 r.; lub co najmniej $30 \%$, w przypadku gdy pracodawca zatrudnia osoby niewidome lub psychicznie chore albo upośledzone umysłowo zaliczone do znacznego albo umiarkowanego stopnia niepełnosprawności). Dodatkowo, obiekty i pomieszczenia użytkowane przez zakład pracy chronionej muszą odpowiadać przepisom i zasadom bezpieczeństwa i higieny pracy oraz muszą uwzględniać potrzeby osób niepełnosprawnych w zakresie przystosowania stanowisk pracy oraz pomieszczeń higieniczno-sanitarnych i ciągów komunikacyjnych oraz spełniać wymagania dostępności do nich, a także musi zostać zapewniona doraźna i specjalistyczna opieka medyczna, poradnictwo i usługi rehabilitacyjne ${ }^{10}$.

10 Za: Art. 28, 30, 31 i 33 ustawy z dnia 27 sierpnia 1997 r. o rehabilitacji zawodowej i społecznej oraz zatrudnianiu osób niepełnosprawnych (Dz.U. z 2011 r. Nr 127, poz. 721, z późn. zm.). 
W 2015 r. w naszym kraju funkcjonowało 1,2 tys. zakładów pracy chronionej, ale ich liczba systematycznie maleje $\mathrm{e}^{11}$.

Zakłady aktywności zawodowej wpisują się już natomiast w ramy systemu ekonomii społecznej, któremu poświęcona będzie dalsza część niniejszego artykułu.

\section{OSOBY NIEPEŁNOSPRAWNE I EKONOMIA SPOŁECZNA}

Podstawowym dążeniem ekonomii społecznej jest osiąganie celów społecznych przy użyciu narzędzi gospodarczych. Podmioty funkcjonujące w jej polu starają się działać w duchu solidarności, partycypacji i samorządności, aby poprzez wybrane instrumenty rynku pracy zapobiegać wykluczeniu społecznemu (w różnych jego przejawach) i animować wspólnotę lokalną. Sektor ekonomii społecznej stara się więc zaspokajać potrzeby tych grup, w przypadku których system społeczny (państwowy, samorządowy) nie okazał się wystarczająco skuteczny.

\section{Czym jest ekonomia społeczna?}

W ramach przeglądu różnych definicji ekonomii społecznej można wyróżnić dwa główne nurty definiowania.

Pierwszy z nich ma charakter normatywny. Takie określanie, czym jest ekonomia społeczna, skupia się przede wszystkim na wyliczaniu atrybutów cechujących działające $\mathrm{w}$ jej ramach podmioty.

Definicja sformułowana przez Europejską Sieć Badawczą (EMES) zwraca uwagę, że o ekonomii społecznej mówimy wtedy, gdy dana działalność łączy w sobie wartości płynące właśnie z tych dwóch porządków - ekonomicznego i społecznego. W tym pierwszym kryterium chodzi więc o takie

11 Za: http://www.niepelnosprawni.gov.pl/p,84,dane-dotyczace-zakladow-pracy-chronionej (dostęp 16.10.2015). 
kwestie, jak: prowadzenie w sposób względnie ciągły, regularny działalności w oparciu o instrumenty ekonomiczne; niezależność, suwerenność instytucji w stosunku do instytucji publicznych; ponoszenie ryzyka ekonomicznego; istnienie choćby nielicznego płatnego personelu. W tym drugim zaś ważna jest: wyraźna orientacja na społecznie użyteczny cel przedsięwzięcia; oddolny, obywatelski charakter inicjatywy; specyficzny, możliwie demokratyczny system zarządzania; możliwie wspólnotowy charakter działania; ograniczona dystrybucja zysków (zob. Defourny 2001).

W innym tekście badacze z EMS Jacques Defourny i Patrick Develtere podkreślają również takie kwestie, jak: nadrzędność świadczenia usług dla członków lub wspólnoty względem zysku; autonomiczne zarządzanie; demokratyczny proces decyzyjny; prymat ludzi i pracy w stosunku do kapitału przy podziale dochodu (2006: 15-16).

Nasz Krajowy Program Rozwoju Ekonomii Społecznej ${ }^{12}$ stwierdza natomiast, że ważnymi założeniami ekonomii społecznej są: budowanie demokracji uczestniczącej i kapitału społecznego poprzez nową wizję ładu społecznego oraz integrację społeczności lokalnych; generowanie wzrostu zatrudnienia poprzez wypełnianie przestrzeni lokalnej $\mathrm{w}$ sferze usług społecznych oraz umożliwianie zatrudnienia przedstawicielom grup szczególnie zagrożonych na rynku pracy; przyczynianie się do integracji społecznej poprzez tworzenie miejsc pracy i zatrudnienie w sektorze ekonomii społecznej; wspieranie rozwoju społeczności lokalnej przez dostarczanie obywatelom niedrogich usług użyteczności publicznej.

Drugie ujęcie ma charakter podmiotowo-instytucjonalny. Oznacza to, że definiowanie płaszczyzny ekonomii społecznej odbywa się poprzez wskazanie typów podmiotów, które działają w jego polu. Najważniejszymi z nich są:

12 Zob. http://www.pozytek.gov.pl/Krajowy,Program,Rozwoju,Ekonomii,Spolecznej,3495.html (dostęp 16.10.2015). 
- spółdzielnie socjalne - przedsiębiorstwa zakładane zarówno przez osoby fizyczne, jak i osoby prawne; mają na celu przede wszystkim społeczną i zawodową reintegrację osób z grup zagrożonych wykluczeniem społecznym (np. długotrwale bezrobotnych, niepełnosprawnych, uzależnionych od alkoholu, narkotyków lub środków odurzających po zakończeniu leczenia, chorych psychicznie, bezdomnych realizujących indywidualny program wychodzenia z bezdomności, osób opuszczających, uchodźców), ale oferujące swoje usługi na otwartym rynku;

- zakłady aktywności zawodowej - stanowią jednostki powoływane zwykle przez gminę lub powiat, których podstawowym zadaniem jest rehabilitacja zawodowa i społeczna osób niepełnosprawnych; dany podmiot musi jednak spełnić szereg warunków, aby stać się ZAZ-em (np. 70\% całej załogi muszą stanowić bowiem osoby niepełnosprawne - ze znacznym lub umiarkowanym stopniem niepełnosprawności);

- centra integracji społecznej - celem działania centrów jest reintegracja zawodowa i społeczna osób zagrożonych wykluczeniem społecznym, a działalność gospodarcza (wytwórcza, handlowa lub usługowa) ma być jedynie środkiem przydatnym w tym właśnie zadaniu;

- warsztaty terapii zajęciowej - uczestnikami WTZ-ów są osoby niepełnosprawne i niezdolne do podjęcia pracy na otwartym rynku, a praca $\mathrm{w}$ ramach WTZ ma być dla nich jedną z form terapii zajęciowej (inne formy ich rehabilitacji to np. ćwiczenia ruchowe, warsztaty psychologiczne i zadania ogólnorozwojowe); działalność WTZ ma charakter niezarobkowy, ale w określonych ramach dopuszcza istnienie dochodu ze sprzedaży produktów i usług wykonanych podczas zajęć; WTZ nie są samodzielną formą prawną, ale wyodrębnioną organizacyjnie i finansowo pla- 
cówką, zakładaną zwykle przez fundacje, stowarzyszenia i inne podmioty;

- organizacje pozarządowe - w nurt ekonomii społecznej wpisują się jednak tylko te fundacje i stowarzyszenia, które dla realizacji celów społecznych prowadzą działalność gospodarczą lub odpłatną;

- instytucje starej ekonomii społecznej - są to spółdzielnie: mieszkaniowe, pracy, rolnicze oraz spółdzielcze banki i kasy oszczędnościowo-kredytowe. Ich celem jest dostarczanie dóbr i usług wykraczających poza potrzeby własnych członków.

Podsumowując zatem różne sposoby ujmowania ekonomii społecznej, niezależnie od przyjętej definicji, zawsze uwypuklone pozostaje to, że jej głównym założeniem (czyli też podstawową zasadą działających w niej podmiotów) jest integracja i aktywizacja grup społecznie wykluczonych lub zagrożonych wykluczeniem poprzez wsparcie ich obecności na lokalnym rynku pracy.

\section{Ekonomia społeczna osób niepełnosprawnych}

Jedną z takich grup stanowią osoby niepełnosprawne. W dalszej części tekstu zostaną przedstawione przykłady dobrych praktyk związanych z działalnością określonych typów podmiotów ekonomii społecznej osób niepełnosprawnych: warsztatów terapii zajęciowej, spółdzielni socjalnych i zakładów aktywności zawodowej. Łączy je także to, że wszystkie one finansowane są w głównej mierze przez PFRON.

\section{Warsztaty terapii zajęciowej (WTZ)}

Jednym z ważnych elementów systemu wsparcia są warsztaty terapii zajęciowej, które funkcjonują na podstawie ustawy o rehabilitacji społecznej i zawodowej osób niepełnosprawnych oraz na podstawie rozporządzenia ministra gospodarki, pracy i polityki społecznej z 25 marca 2004 r. w sprawie warsztatów terapii zajęciowej. Do warsztatów 
trafiają osoby niepełnosprawne, które posiadają wskazanie do rehabilitacji w WTZ wydane przez powiatowe/miejskie zespoły ds. orzekania o niepełnosprawności. Koszty utworzenia, działalności WTZ są współfinansowane ze środków Państwowego Funduszu Rehabilitacji Osób Niepełnosprawnych oraz ze środków samorządu powiatowego.

W ramach terapii prowadzone są pracowanie „tematyczne" (np. gospodarstwa domowego, stolarska, plastyczna, komputerowa), w których odbywa się rehabilitacja społeczna i zawodowa. Według ustawy na jedną osobę pracującą bezpośrednio $\mathrm{z}$ uczestnikami nie powinno przypadać więcej niż pięciu uczestników warsztatów, co oznacza, że przeważnie do jednej pracowni tematycznej uczęszcza pięciu uczestników, których opiekunem jest jeden terapeuta.

Według badań przeprowadzonych na zlecenie PFRON, w Polsce w 2013 r. funkcjonowało 684 WTZ, do których uczęszczało 24871 osób (Morysińska i in. 2014: 6).

Zgodnie z tymi badaniami, w skali całego kraju, bez tego typu wsparcia pozostaje obecnie 25 powiatów: 6 powiatów z województwa mazowieckiego, $5 \mathrm{z}$ dolnośląskiego, po $3 \mathrm{z}$ zachodniopomorskiego i pomorskiego, po 2 z łódzkiego, wielkopolskiego oraz kujawsko-pomorskiego oraz po $1 \mathrm{z}$ opolskiego i lubuskiego. Najszerszy dostęp do tego typu formy rehabilitacji odnotowano w województwach: lubelskim, małopolskim, podlaskim, świętokrzyskim, wielkopolskim oraz podkarpackim.

Głównym inicjatorem powstawania warsztatów są przede wszystkim organizacje pozarządowe, natomiast sam samorząd terytorialny w mniejszym stopniu podejmuje się powołania formy wsparcia, jakim jest WTZ (ibidem: 7). Większość działających w Polsce warsztatów terapii zajęciowej wśród uczestników nie ma jednej dominującej ze względu na rodzaj niepełnosprawności grupy. Jednak 43\% WTZ przyjmuje do siebie osoby o jednym dominującym rodzaju niepełnosprawności (przede wszystkim niepełnosprawność intelektualna, psychiczna). 
Celem funkcjonowania WTZ jest przede wszystkim zapewnienie osobom $\mathrm{z}$ niepełnosprawnościami niezdolnym do podjęcia pracy (w stopniu umiarkowanym i znacznym) możliwości rehabilitacji społecznej i zawodowej w zakresie pozyskania lub przywracania umiejętności niezbędnych do podjęcia zatrudnienia. Powinno się to odbywać za pomocą technik terapii zajęciowej zmierzających do rozwijania umiejętności wykonywania czynności życia codziennego oraz zaradności osobistej, psychofizycznych sprawności oraz podstawowych i specjalistycznych umiejętności zawodowych, umożliwiających uczestnictwo w szkoleniu zawodowym albo podjęcie pracy.

Jednak, jak wynika z ww. badań PFRON w WTZ, jest bardzo mała rotacja uczestników, tzn. dane ilościowe dotyczące czasu pozostawania uczestników w WTZ, regułą jest przedłużenie czasu pobytu ponad przewidziane 3 lata (Proresearch 2012: 115), a nawet średni czas pozostawania uczestników w WTZ to 7 lat i 8,5 miesiąca (w 2013 r. warsztaty terapii zajęciowej opuszczały średnio 2,5 osoby [Morysińska i in. 2014: 7]).

Konsekwencją niedoboru odpowiedniej liczby ośrodków wsparcia dla osób niepełnosprawnych w systemie pomocy społecznej jest kierowanie do warsztatów osób, które nie powinny przebywać w tego typu ośrodkach, np. osoby, które wymagają całodobowej medycznej opieki specjalistycznej. Tego typu sytuacje przyczyniają się do pogłębienia nieefektywności systemu rehabilitacji społecznej i zawodowej, ponieważ WTZ nie mogą w pełni realizować swoich programów rehabilitacji. Mimo intencji ustawodawcy, mechanizm polegający na czasowym pobycie osób w WTZ, gdzie w ramach indywidualnego programu rehabilitacji nabywają one kompetencje umożliwiające im podjęcie zatrudnienia, najpierw na chronionym (zakład aktywności zawodowej, zakład pracy chronionej), a potem na otwartym rynku pracy, nie przynosi pożądanych rezultatów. W związku z tym WTZ stają się miejscem nie tyle 
przejściowym, co docelowym, pełniąc wbrew ustawie rolę ośrodków wsparcia.

Wiele jest czynników, które powodują niemożność funkcjonowania WTZ jako miejsca przejściowego dla osób niepełnosprawnych $\mathrm{w}$ procesie rehabilitacji zawodowej, są to m.in.: niedostosowanie rynku pracy do potrzeb i możliwości osób niepełnosprawnych, brak przygotowania pracodawców do zatrudnienia podopiecznych WTZ, brak systemu kompleksowego wsparcia byłych uczestników WTZ w miejscu pracy, brak chęci zmiany swojej sytuacji przez uczestników lub ich rodziny, brak dostępu uczestników do instytucji (WTZ do ZAZ, ZPCH), brak narzędzi do realizacji integracji zawodowej, niedoskonałość systemu orzecznictwa.

W działalności warsztatów brak jest również wypracowanych standardów i wyraźnych wzorców w zakresie funkcjonowania, co $\mathrm{w}$ pewien sposób może utrudnić proces rehabilitacji społecznej i zawodowej uczestników. Każdy z WTZ stosuje własny wzór IPR (składający się przeważnie z: rehabilitacji społecznej, zawodowej, treningu ekonomicznego, rehabilitacji psychologicznej, ruchowej oraz planu współpracy z rodzicami/opiekunami), prowadzenia dokumentacji uczestników czy pracy rady programowej. Niektóre silne organizacje prowadzące warsztaty tworzą własne standardy pracy swoich WTZ-ów (np. Polskie Stowarzyszenie na rzecz Osób z Niepełnosprawnością Intelektualną). Stworzenie standardów w tym wypadku przyczynia się do możliwości porównania pracy poszczególnych jednostek. Wartym opisania jest również Gdyński standard aktywizacji zawodowo-społecznej w Warsztatach Terapii Zajęciowej, który określił organizację i zasady funkcjonowania WTZ w Gdyni, tym samym ujednolicił proces rehabilitacji osób niepełnosprawnych przebywających w WTZ. Standard zawiera m.in. opis takich aspektów, jak: trening ekonomiczny, wykształcenie kadry, rekrutacja, kwalifikacja kandydatów oraz skreślenie z listy uczestników WTZ, sposób prowadzenia ewaluacji, wzory dokumentów, kata- 
log kosztów kwalifikowanych WTZ. Co ciekawe, standard został wypracowany razem z Miejskim Ośrodkiem Pomocy Społecznej w Gdyni, który jest jednostką nadzorującą gdyńskie WTZ. Tym samym do standardu zostały również włączone wytyczne kontroli.

W przypadku pracy WTZ-ów ważnym aspektem jest też wymiana doświadczeń pomiędzy warsztatami oraz współpraca $\mathrm{z}$ innymi instytucjami systemu pomocy społecznej. Taką przestrzenią mogą być utworzone w 14 województwach fora warsztatów terapii zajęciowej. We wrześniu bieżącego roku w Krakowie zostało powołane Ogólnopolskie Forum WTZ, które będzie przede wszystkim miejscem wymiany doświadczeń, reprezentowania środowiska WTZ i ich organizatorów oraz inicjowania i monitorowania prac legislacyjnych toczących się wokół WTZ. Taka forma organizacji środowiska może się przyczynić do wymiany dobrych praktyk w zakresie rehabilitacji osób niepełnosprawnych. Ciekawym rozwiązaniem jest zatrudnienie do dyspozycji warsztatów trenera pracy. Jego zadaniem jest współpraca z pracodawcami, a także wsparcie uczestnika warsztatu w zdobywaniu nowych umiejętności, kompetencji na przyszłym stanowisku pracy. W Poznaniu w ramach projektów przy Stowarzyszeniu Na Tak (Stowarzyszenie jest twórcą dwóch WTZ) powstała Agencja Zatrudnienia Wspomaganego BIZON. Agencja świadczy usługi dla osób niepełnosprawnych zatrudnienia wspomaganego. Celem agencji jest m.in. stworzenie profilu zawodowego oraz wielowymiarowe przygotowanie klienta do wejścia na rynek pracy - zaplanowanie działań, pomoc w poszukiwaniu pracy, pośrednictwo pracy, dobór odpowiedniego pracodawcy do odpowiedniego pracownika, bezpośredni kontakt z pracodawcą, omówienie warunków pracy, płacy, zakresu obowiązków, wspólne dostosowanie stanowiska pracy do oczekiwań pracodawcy i możliwości pracownika ${ }^{13}$. Współpraca WTZ-ów z tego

${ }^{13}$ Informacje pozyskane ze strony http://bizon.org.pl (dostęp 16.10.2015). 
typu agencją umożliwi lepsze przygotowanie uczestników do podjęcia pracy, a tym samym zwiększy rotację uczestników warsztatów.

\section{Zakłady aktywności zawodowej (ZAZ)}

Kolejną formą wsparcia skierowaną do osób niepełnosprawnych są zakłady aktywności zawodowej (ZAZ). Organem prowadzącym zakład może być gmina, powiat albo organizacja pozarządowa. Funkcjonowanie ZAZ jest regulowane przez ustawę o rehabilitacji zawodowej i społecznej oraz zatrudnieniu osób niepełnosprawnych oraz liczne rozporządzenia ministrów. ZAZ działają w celach rehabilitacji zawodowej i społecznej osób z niepełnosprawnościami i jest ich obecnie w Polsce 92 (dane MPIPS za czerwiec 2015) ${ }^{14}$. Profile działalności zakładów są bardzo różne - od usług poligraficznych, przez usługi hotelarskie po wprowadzanie i przetwarzanie danych (79\% ZAZ-ów ma charakter produkcyjno-usługowy, w tym 40\% świadczy usługi cateringowe [za: Morus, Księżopolska, Żuchowski 2014: 8]). Pracownikami zakładów są głównie osoby niepełnosprawne o stopniu umiarkowanym i znacznym (co najmniej $70 \%$ ogółu zatrudnionych w tej jednostce muszą stanowić osoby niepełnosprawne). Jak wynika również z zapisów ustawy, zatrudnienie w zakładzie aktywności zawodowej jest formą zatrudnienia chronionego (inną formą zatrudnienia chronionego jest zakład pracy chronionej).

W odróżnieniu od WTZ status ZAZ jest inny, ponieważ WTZ jest jednym $z$ instrumentów rehabilitacji społeczno-zawodowej (innym instrumentem są turnusy rehabilitacyjne). Wśród pracowników ZAZ najwięcej jest osób chorujących psychicznie $(35,5 \%)$ i z niepełnosprawnością intelektualną (21\%) oraz $\mathrm{z}$ dysfunkcjami narządu ruchu $(18,3 \%)$ (ibidem: 14$)$.

14 Informacje pozyskane ze strony http://www.niepelnosprawni.gov. pl (dostęp 16.10.2015). 
ZAZ-y oferują bardzo dobre warunki chronionych miejsc pracy (Kublicka, Łukasiewicz, Stronkowski 2014: 151), jednak dostępne są one jedynie dla nielicznych osób. Według danych BAEL liczba osób niepełnosprawnych w wieku 16 lat i więcej w 2014 r. kształtowała się na poziomie 3,3 mln osób (dokładnie 3272 tys.), natomiast liczba osób niepełnosprawnych prawnie $\mathrm{w}$ wieku produkcyjnym ze stopniem umiarkowanym i znacznym wynosiła średniorocznie 1344 tys., tylko 2,3 \% pracowało w ZAZ-ach (opracowanie własne na podstawie danych MPIPS ${ }^{15}$ ). Funkcjonowanie zakładów aktywności zawodowej jest finansowane ze środków PFRON, samorządu województwa, z pieniędzy uzyskanych z realizacji wykonywanych usług oraz z Systemu Obsługi Dofinansowań „SOD”.

Tak samo jak w WTZ problemem jest bardzo niski poziom rotacji pracowników (44\% pracowników ZAZ-ów pracuje w nich powyżej 5 lat (za: Morus, Księżopolska, Żuchowski 2014: 15). Jest to spowodowane głównie konstrukcją umów o pracę, które posiadają osoby pracujące w ZAZ-ach, ale na ten stan rzeczy wpływają też inne czynniki. Oczywiście należy sobie zdać sprawę, że w ZAZ-ach pracują również osoby niepełnosprawne, które nigdy nie znajdą zatrudnienia na otwartym rynku pracy i ZAZ będzie ich miejscem docelowym pracy.

Podstawowym instrumentem rehabilitacji w ZAZ-ach jest praca wykonywana przez osoby niepełnosprawne. Diagnoza w ZAZ odbywa się głównie pod kątem możliwości wykonywania danej pracy, jednak nie jest to proces ustandaryzowany na poziomie ogólnokrajowym. Na tej podstawie tworzony jest indywidualny plan rehabilitacji, który zawiera często ogólne, nieweryfikowalne cele i rutynowe działania ZAZ, nie przewiduje jednak ścieżki rehabilitacji, która ma doprowadzić do usamodzielnienia się pracowników (Kublicka, Łukasiewicz, Stronkowski 2014: 140).

15 Pozyskane dane ze strony http://www.niepelnosprawni.gov. $\mathrm{pl} / \mathrm{p}, 79$, informacje-i-dane-demograficzne (dostęp 16.10.2015). 
Jednym z ważnych problemów również wpływających na niski stopień „wychodzenia” pracowników ZAZ na otwarty rynek pracy pozostaje brak mechanizmów ułatwiających opuszczenie zakładu i zdobycie doświadczenia (praktyki, staże u innych pracodawców), a także wspierających osobę na otwartym rynku pracy (zatrudnienie wspomagane - trener pracy). Istotnym problemem w tym wypadku jest brak mechanizmów motywujących ZAZ do bardziej aktywnego zabiegania o podjęcie pracy przez pracowników poza ZAZ (ibidem: 150).

Zarówno w przypadku WTZ, jak i ZAZ brakuje narzędzia, które mierzyłoby efekt reintegracyjny. Odpowiedzią na ten problem może być stworzone przez ROPS w Poznaniu narzędzie do mierzenia efektu reintegracyjnego (społecznego). Proces reintegracji odbywający się $\mathrm{w} w \mathrm{w}$. podmiotach jest najważniejszym elementem rozpoczynającym proces włączenia uczestników/pracowników do społeczeństwa. Jest on wręcz niezbędny, aby osiągnąć kolejny efekt, jakim jest efekt zatrudnieniowy. Narzędzie obecnie pozostaje w fazie pilotażu i ma służyć również klubom integracji społecznej i centrom integracji społecznej. Jego elementem jest tworzenie indywidualnych planów rehabilitacji w taki sposób, aby zawierały weryfikowalne cele i tworzyły realne ścieżki rehabilitacji.

Ciekawym rozwiązaniem, które tak jak w przypadku WTZ stanowi przestrzeń do wymiany doświadczeń, jest Ogólnopolski Związek Pracodawców Zakładów Aktywności Zawodowej. Głównym celem Związku jest rozwój i wzmocnienie potencjału oraz ochrona praw i reprezentowanie interesów zrzeszonych pracodawców na zewnątrz, w tym wobec organów władzy publicznej ${ }^{16}$.

16 Informacje pozyskane ze strony http://zazpolska.pl/zarzad-zpzaz (dostęp 16.10.2015). 


\section{Spółdzielnie socjalne}

Problem ZAZ/WTZ dotyczący rotacji uczestników/ pracowników został rozwiązany przez niektóre organy prowadzące tego typu formy wsparcia poprzez stworzenie spółdzielni socjalnych funkcjonujących przy zakładach i warsztatach. Spółdzielnia socjalna ma służyć w ten sposób uskutecznieniu zapoczątkowanych w WTZ/ZAZ procesów integracji/aktywizacji społecznej i zawodowej uczestników. W tym wypadku spółdzielnia stała się dodatkowym instrumentem rehabilitacji społecznej i zawodowej osób niepełnosprawnych, pozwalającym stworzyć realne miejsca pracy oraz przestrzeń przygotowywania do pracy w formie praktyk zawodowych i staży dla uczestników/pracowników.

Spółdzielnie socjalne według ustawy o spółdzielniach socjalnych mogą założyć osoby fizyczne (w tym wypadku liczba nie może być mniejsza niż pięć) ${ }^{17}$, organizacje pozarządowe w rozumieniu przepisów o działalności pożytku publicznego i o wolontariacie lub jednostki samorządu terytorialnego, kościelne osoby prawne (liczba założycieli nie może być mniejsza niż dwóch). Pomimo to, że osoby niepełnosprawne mogą być członkami założycielami spółdzielni, w przypadku osób z niepełnosprawnością intelektualną (a takie osoby są głównie uczestnikami WTZ i częścią pracowników ZAZ) lepszym rozwiązaniem jest, gdy to dwa podmioty o osobowości prawnej założą spółdzielnię funkcjonującą przy WTZ/ZAZ. Powoduje to bowiem

17 Art. 4. 1. ustawy z dnia 27 kwietnia 2006 r. o spółdzielniach socjalnych mówi, że spółdzielnię socjalną mogą założyć: 1 . osoby bezrobotne, w rozumieniu art. 2 ust. 1 pkt 2 ustawy z dnia 20 kwietnia 2004 r. o promocji zatrudnienia i instytucjach rynku pracy (Dz.U. Nr 99, poz. 1001, z późn. zm.), 2. osoby, o których mowa w art. 1 ust. 2 pkt 1-4, 6 i 7 ustawy z dnia 13 czerwca 2003 r. o zatrudnieniu socjalnym (Dz.U. Nr 122, poz. 1143, z późn. zm.), 3. osoby niepełnosprawne, w rozumieniu ustawy z dnia 27 sierpnia 1997 r. o rehabilitacji zawodowej i społecznej oraz zatrudnianiu osób niepełnosprawnych (Dz.U. Nr 123, poz. 776, z późn. zm.) - posiadające pełną zdolność do czynności prawnych. 
większą trwałość funkcjonowania podmiotu (najczęściej organizatorzy ZAZ/WTZ zakładają spółdzielnię). Dzięki temu podmiot prowadzący zyskuje nowe narzędzie rehabilitacji i miejsce praktyk, staży. Na sfinansowanie powstania spółdzielni socjalnych można pozyskać środki pochodzące zarówno z Unii Europejskiej (głównie z Regionalnych Programów Operacyjnych), środki samorządów, jak i środki z Państwowego Funduszu Rehabilitacji Osób Niepełnosprawnych oraz Funduszu Pracy.

Spółdzielnia socjalna przyczynia się też do wzrostu zatrudnienia osób niepełnosprawnych w szczególności z niepełnosprawnością intelektualną (uczestników WTZ), którzy są szczególną grupą na rynku pracy. Powstały nowe miejsca pracy, a także miejsca praktyk i staży, które są dostępne dla większej liczby uczestników WTZ i pracowników ZAZ. W szczególności $\mathrm{w}$ przypadku spółdzielni socjalnych powstałych przy warsztatach zauważalny jest rozwój umiejętności miękkich, tj. komunikacji interpersonalnej, samodzielności, pewności siebie, obowiązkowości, ale dzięki pracy w spółdzielni socjalnej zauważalny jest też postęp w rehabilitacji społecznej i zawodowej. Osoby te zyskały możliwość rozwoju umiejętności planowania dnia i organizacji pracy, zdobycia doświadczenia na otwartym rynku pracy, zwiększył się zakres podejmowanych przez nich samodzielnie działań, pojawiła się odpowiedzialność za sprzęt czy wykonywane zadania, a także wzrost motywacji i podniesienie umiejętności w kontaktach interpersonalnych. Ponadto, poprzez płynne przejścia osób niepełnosprawnych z WTZ/ZAZ do spółdzielni socjalnej możliwa jest wreszcie rotacja samych uczestników WTZ/pracowników ZAZ. Środki finansowe, które osoby niepełnosprawne zarobily w wyniku pracy, mogą one przeznaczyć na własne potrzeby lub dołożyć się do rodzinnych rachunków, tak jak i ich pełnosprawni znajomi i rodzina. 


\section{Współpraca WTZ - ZAZ - spółdzielnia socjalna}

Współpraca między tymi trzema typami podmiotów WTZ, ZAZ i spółdzielnią socjalną - jest szansą na udoskonalenie systemu pomocy społecznej. Dzieje się to poprzez przemianę osób niepełnosprawnych korzystających z pomocy społecznej w pracowników, poprawę jakości ich życia, wzrost poczucia własnej wartości i idące za tym korzyści społeczne, a w konsekwencji wyjście z wykluczenia. Ważna jest ścisła współpraca między WTZ/ZAZ i spółdzielnią socjalną poprzez np. program praktyk i staży realizowanych przez WTZ/ZAZ w spółdzielni, dostosowanie indywidualnych programów rehabilitacji realizowanych przez WTZ/ ZAZ do potrzeb kompetencyjnych i w zakresie umiejętności potrzebnych w spółdzielniach socjalnych. Aktywizacja zawodowa osób niepełnosprawnych jest ważnym celem polityki społecznej $\mathrm{w}$ kontekście aktualnych problemów demograficznych. Osoby przebywające w WTZ/ZAZ mogą stać się dzięki pracy w spółdzielni socjalnej pełnoprawnymi uczestnikami życia społecznego.

Istotnym elementem pracy w spółdzielni jest oparcie jej powstawania i funkcjonowania o partnerstwa lokalne (biznes, samorząd, organizacje pozarządowe), a także zwrócenie uwagi na oddolny charakter tego rozwiązania, co daje większą trwałość wypracowanego rozwiązania. Brak partnerstwa lokalnego czy źle skonstruowany biznesplan mogą doprowadzić do nierentowności spółdzielni, a tym samym do jej likwidacji. Jednak najważniejszym ogniwem powodzenia tego typu przedsięwzięć jest pomysł na rodzaj działalności gospodarczej dostosowanej do potrzeb i możliwości, również typu niepełnosprawności pracowników spółdzielni oraz przede wszystkim dostosowanej do potrzeb lokalnego rynku. Ważne jest także zatrudnienie w spółdzielni asystenta pracy osób niepełnosprawnych oraz dostosowanie liczby godzin praktyk, stażu do potrzeb przyszłych pracowników, którzy będą wykonywać często nowe czynności (w przypadku spółdzielni produkcyjnych czas praktyk powinien być większy). Dobór 
odpowiedniej osoby na stanowisko asystenta pracy jest równie istotny jak rekrutacja lidera spółdzielni socjalnej. Osoba zatrudniona jako asystent pracy osoby niepełnosprawnej ma za zadanie przede wszystkim pomagać tej osobie w zakresie czynności ułatwiających komunikowanie się z otoczeniem oraz czynności niemożliwych lub trudnych do samodzielnego wykonania na danym stanowisku pracy.

Dobrym przykładem partnerstwa $\mathrm{z}$ biznesem i pomysłu na działalność gospodarczą dostosowaną do osób niepełnosprawnych jest Spółdzielnia Socjalna „Aktywni” z Koła. Spółdzielnia zatrudnia osoby z niepełnosprawnością intelektualną. Partnerstwo zostało zawiązane między spółdzielnią a firmą Saint-Gobain HPM Polska Sp. z o.o. Współpraca ze Spółdzielnią Socjalną „Aktywni” odbywa się głównie w ramach podwykonawstwa prac związanych z co-packingiem materiałów ściernych. W ramach wykonywanych obowiązków Spółdzielnia Socjalna zajmuje się również pielęgnowaniem terenów zielonych oraz kostki brukowej na terenie zakładu. Obecnie spółdzielnia prowadzi także niepubliczne przedszkole ${ }^{18}$.

Innym ciekawym przykładem jest Spółdzielnia Socjalna „OPOKA” z Kluczy. Jest pierwszą w Polsce spółdzielnią socjalną, którą założyły dwa podmioty prawne - Stowarzyszenie na Rzecz Zrównoważonego Rozwoju Społeczno-Gospodarczego „KLUCZ” i Chrześcijańskie Stowarzyszenie Dobroczynne. Spółdzielnia działa w branży gastronomicznej i szkoleniowej ${ }^{19}$. Interesujące jest to, że spółdzielnia w $2012 \mathrm{r}$. założyła zakład aktywności zawodowej. ZAZ powstał jako brakujące ogniwo $\mathrm{w}$ procesie przejścia osób niepełnosprawnych z WTZ do spółdzielni. Jedno ze stowarzyszeń tworzących prowadziło warsztaty terapii zajęciowej, które nie przygotowywały uczestników do wejścia na rynek pracy.

18 Informacje pozyskane ze strony http://aktywni.spoldzielnie.org/ partnerzy/ (dostęp 16.10.2015).

19 Informacje pozyskane ze strony http://www.ekonomiaspoleczna. pl/wiadomosc/787828.html (dostęp 16.10.2015). 


\section{REKOMENDACJE}

Niniejszy tekst przedstawił wiele szans, które stwarzają dla osób niepełnosprawnych podmioty ekonomii społecznej. Jednocześnie wskazał on także liczne problemy i bariery funkcjonowania tychże przedsiębiorstw. W związku z tym warto zastanowić się nad działaniami, które mogą usprawnić efektywność tego sektora. Oto dziesięć propozycji.

Po pierwsze, stworzenie narzędzia badającego efekt reintegracyjny (społeczny) zakładów aktywności zawodowej i warsztatów terapii zajęciowej, ponieważ obecnie mierzony jest tylko efekt zatrudnieniowy tych podmiotów. Jednak ten sposób pomiaru efektów pracy WTZ/ZAZ jest niewystarczający. ROPS w Poznaniu podjął się próby stworzenia takiego narzędzia. Jest on obecnie $\mathrm{w}$ fazie pilotażu.

Po drugie, standaryzacja narzędzi wspierających procesy diagnozy uczestników WTZ/ZAZ, wyznaczania celów integracji i rehabilitacji, a także monitorowania postępów uczestników.

Po trzecie, tworzenie mechanizmów umożliwiających odbywanie praktyk i staży (uregulowanych prawnie) uczestników WTZ/pracowników ZAZ na otwartym rynku pracy, przy wykorzystaniu mechanizmów zatrudnienia wspomaganego (trener pracy).

Po czwarte, stworzenie mechanizmów motywacyjnych dla ZAZ do bardziej aktywnego przygotowania pracownika do podjęcia zatrudnienia na otwartym rynku pracy. W przypadku WTZ mechanizm motywacyjny musiałby polegać na wsparciu w zakresie lepszego przygotowania uczestników na chroniony/otwarty rynek pracy (zatrudnienie trenera pracy, współpraca $\mathrm{z}$ doradcą zawodowym, współpraca z pracodawcami).

Po piąte, stworzenie większej liczby ośrodków wsparcia dla osób z niepełnosprawnościami, do których mogłyby trafić osoby wymagające specjalistycznej całodziennej opieki i nierokujące postępów w rehabilitacji prowadzonej w WTZ. 
Po szóste, dostosowanie profilu pracowni w WTZ do lokalnego rynku pracy, przy współpracy z pracodawcami.

Po siódme, stworzenie platformy wymiany doświadczeń pomiędzy poszczególnymi aktorami systemu i środowiska osób z niepełnosprawnościami (WTZ, ZAZ, jednostki samorządu terytorialnego, pracodawcy). Dobrym rozwiązaniem jest tworzenie grup lokalnych, regionalnych zrzeszających ww. podmioty.

Po ósme, dbałość o to, aby pomimo afirmacji rozwiązań, jakie niesie za sobą funkcjonowanie w ramach systemu ekonomii społecznej, informować również zainteresowane jednostki o zagrożeniach/problemach, jakie wiążą się np. z zakładaniem spółdzielni socjalnej lub zbyt długim przebywaniem w WTZ.

Po dziewiąte, zwiększenie współpracy spółdzielni socjalnej z biznesem, społecznością lokalną na zasadach partnerskich, co zapewni stabilność, trwałość funkcjonowania spółdzielni.

Po dziesiąte, dostosowanie czasu praktyk i staży w spółdzielni socjalnej do potrzeb osób niepełnosprawnych i do rodzaju działalności.

Wdrożenie zaproponowanych rekomendacji oczywiście nie gwarantuje rozwiązania wszystkich problemów podmiotów ekonomii społecznej zatrudniających osoby niepełnosprawne. Skupienie się jednak na usprawnieniu zdiagnozowanych już „usterek” z pewnością podniesie jakość ich funkcjonowania $\mathrm{w}$ wybranych obszarach, a w efekcie również „społeczną wydajność” tychże podmiotów.

\section{BIBLIOGRAFIA}

Brzezińska Anna, Kaczan Radosław, Rycielska Ludmiła (2010), Przekonania o swoim życiu. Spostrzeganie historii życia przez osoby z ograniczeniami sprawności, Wydawnictwo Naukowe Scholar, Warszawa. 
Defourny Jacques (2001), From Third Sector to Social Enterprise, [w:] Carlo Borzaga, Jacques Defourny (eds.), The Emergence of Social Enterprise, Routledge, London-New York, s. 1-28.

Defourny Jacques, Develetere Patrick (2006), Ekonomia społeczna: ogólnoświatowy trzeci sektor, [w:] Jakub Wygnański (red.), Trzeci sektor dla zaawansowanych, Stowarzyszenie Klon/Jawor, Warszawa, s. 15-42.

Goffman Erving (1981), Człowiek $w$ teatrze życia codziennego, Państwowy Instytut Wydawniczy, Warszawa.

Morysińska Agnieszka, Marzena Sochańska-Kawiecka, Edyta Makowska-Belta, Dorota Zielińska, Dominika Milczarek, Elżbieta Zakrzewska-Manterys, Agnieszka Kumaniecka (2014), Badanie sytuacji warsztatów terapii zajęciowej. Raport końcowy $z$ badania. Raport na zlecenie PFRON zrealizowany przez Laboratorium Badań Społecznych, http://www.pfron.org.pl/download/1/5062/RaportkoncowyWTZ.pdf (dostęp 9.10.2015).

Morus Maria, Księżopolska Katarzyna, Żuchowski Grzegorz (2014), Zakłady Aktywności Zawodowej w 2013 r. Informacja z badania, Raport z badań PFRON, http://www.pfron.org.pl/ download/1/3431/zaz2013.pdf (dostęp 10.10.2015).

Raport z badania aktywizacji osób niepetnosprawnych przy wykorzystaniu modeli zakładajacych tworzenie spółdzielni socjalnych przy warsztatach terapii zajęciowej. Raport powstały w ramach projektu „Innowacyjny model aktywizacji zawodowej uczestników WTZ” zrealizowany przez IBS Proresearch, http://www. wtz.spoldzielnie.org/images/za.\%206\%20raport\%20z\%20 badania\%20aktywizacji\%20osb\%20niepenosprawnych\%20 przy\%20wykorzystaniu\%20modeli\%20zakadajcych\%20tworzenie\%20sps\%20przy\%20wtz.pdf (dostęp 5.10.2015).

Stronkowski Piotr, Kublicka Michalina, Łukasiewicz Aleksandra (2014), Badanie monitoringowe sektora ekonomii społecznej oraz jakości wsparcia i efektów działania $w$ obszarze reintegracji społecznej i zawodowej podmiotów ekonomii społecznej ze wskazaniem rekomendacji dla systemu monitoringu, Raport na zlecenie Regionalnego Ośrodka Polityki Społecznej w Poznaniu zrealizowany przez Centrum Doradztwa Społeczno-Gospodarczego w Szczecinie, http://www. rops.poznan.pl/aktualnosci/ raport-z-badania-podmiotowreintegracyjnych-cis-kis-zaz-wtz-spoldzielni-socjalnych. html (dostęp 10.10.2015). 


\section{DISABLED AS WORKING IN THE SYSTEM OF SOCIAL ECONOMY}

(Summary)

Social economy is an important area of the social integration. It uses economic tools to keep the margin groups in the core of social life. The one of the margin groups are disabled people. Social economy offers them the wide scope of the social entrepreneurship models. We would focus on three of them: therapeutic session tool-room, labour activation plant and disabled people social cooperatives. This text analyse both advantages and disadvantages of these social economy subjects.

Keywords: labour market, social economy, social entrepreneurship, therapeutic session tool-room, labour activation plant, disabled people social cooperatives. 